\title{
Technè
}

La science au service de l'histoire de l'art et de la préservation des biens culturels

$43 \mid 2016$

Une Europe de la recherche en sciences du patrimoine

\section{Characterisation of metallic mordants in Subarctic Athapaskan quillwork: a PIXE-RBS study on replicate samples}

Caractérisation de mordants métalliques dans des ornements en piquants de porc-épic (culture Athapaskan subarctique) : une étude PIXE-RBS sur des échantillons re-créés en laboratoire

Lore Troalen, Thomas Calligaro, Claire Pacheco and Alison N. Hulme

\section{OpenEdition}

Journals

Electronic version

URL: http://journals.openedition.org/techne/821

DOI: 10.4000/techne.821

ISSN: 2534-5168

Publisher

C2RMF

Printed version

Date of publication: 1 August 2016

Number of pages: 102-109

ISBN: 978-2-7118-6338-9

ISSN: $1254-7867$

Electronic reference

Lore Troalen, Thomas Calligaro, Claire Pacheco and Alison N. Hulme, "Characterisation of metallic mordants in Subarctic Athapaskan quillwork: a PIXE-RBS study on replicate samples », Technè [Online], 43 | 2016, Online since 19 December 2019, connection on 23 July 2020. URL : http:// journals.openedition.org/techne/821; DOI : https://doi.org/10.4000/techne.821

La revue Technè. La science au service de l'histoire de l'art et de la préservation des biens culturels est mise à disposition selon les termes de la Licence Creative Commons Attribution - Pas d'Utilisation Commerciale - Pas de Modification 4.0 International. 


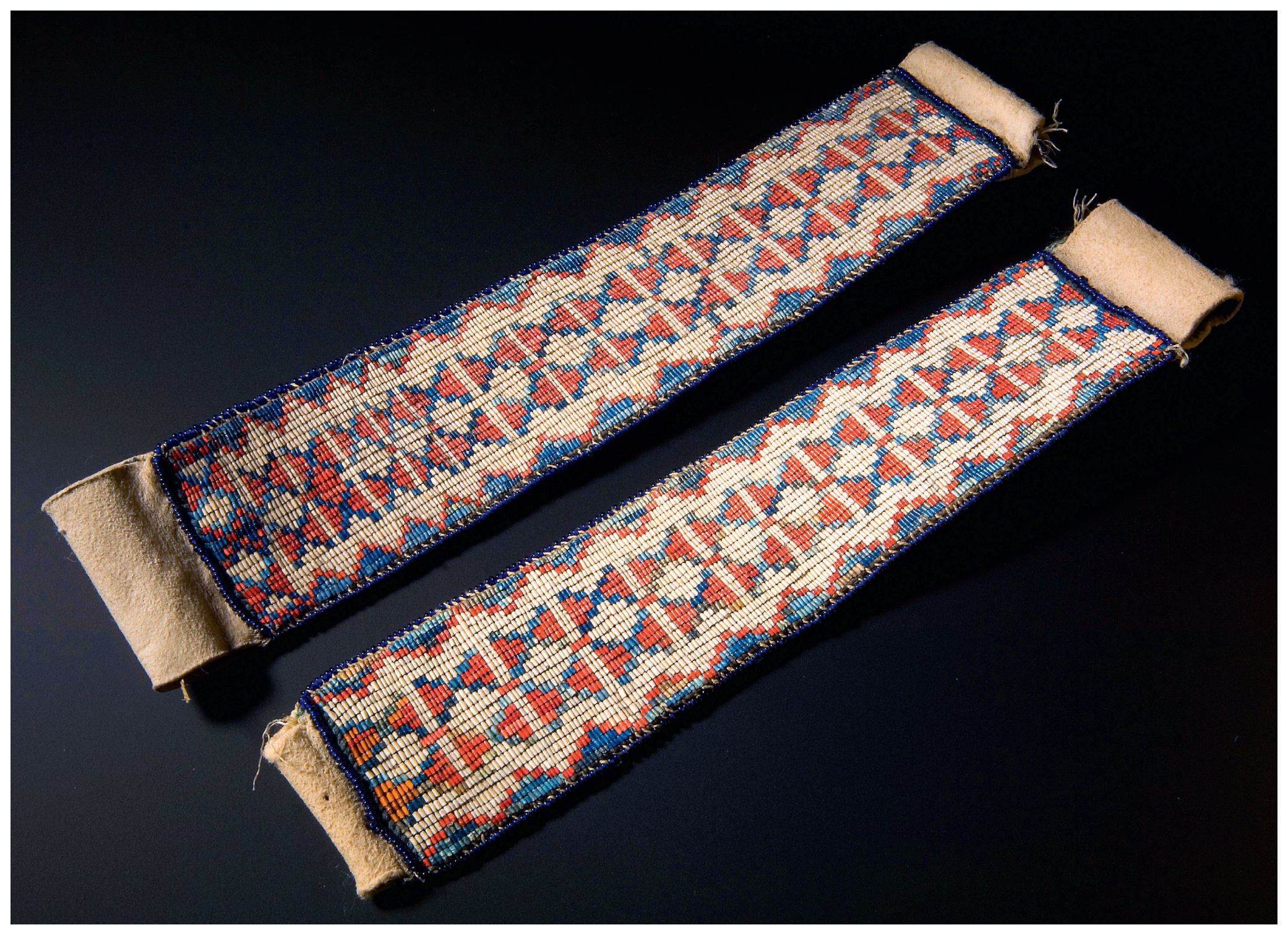

Fig. 1. Bracelet of tanned caribou skin decorated with porcupine quills and blue beads,

Athapaskans (Acc. $\mathrm{N}^{\circ}$ : A.849.6). ( ) National Museums Scotland/Photography Neil McLean. 
Lore Troalen

Thomas Calligaro

Claire Pacheco

Alison N. Hulme

\section{Characterisation of metallic mordants in Subarctic Athapaskan quillwork: a PIXE-RBS study on replicate samples}

Caractérisation de mordants métalliques dans des ornements en piquants de porc-épic (culture Athapaskan subarctique) : une étude PIXE-RBS sur des échantillons re-créés en laboratoire
Abstract. Native American quillwork collections remain little studied due to the limited availability of quillwork material for sampling. In this paper we explore the use of non-invasive Particle Induced X-Ray Emission (PIXE) and Rutherford Backscattering Spectrometry (RBS) to characterise metallic residues in a set of modern porcupine quills prepared with a range of metallic mordants. PIXE analysis was used to determine the concentrations of various mordants present, while RBS analysis allowed additional information on the depth-profiling of the mordants at the surface of the quills to be obtained.

Keywords. Quillwork, porcupine quills, dyeing practices, metallic mordants, Northern Athapaskans, PIXE analysis, RBS analysis.
Résumé. Les collections nord-amérindiennes décorées avec la technique de la teinture des piquants de porc-épic restent très peu étudiées, en raison de la difficulté de prélever ce type de collections. Dans cet article, nous explorons l'utilisation de l'analyse par faisceau d'ions (PIXE-RBS) pour la caractérisation de résidus métalliques sur des piquants de porc-épic de référence préparés en laboratoire avec différents mordants. L'analyse PIXE nous a permis de caractériser les concentrations de mordants métalliques présents à la surface des piquants de porc-épic, tandis que l'analyse par rétrodiffusion de Rutherford (RBS) nous a permis d'obtenir des informations complémentaires sur la répartition de ces mordants dans les couches superficielles de la kératine.

Mots-clés. Travail aux piquants, piquants de porc-épic, teinture, mordançage, Athapaskan du Nord, analyse PIXE, analyse RBS.

\section{Introduction}

Indigenous communities across North America, from the North American Subarctic, Great Lakes region and the Northern Plains, have long used dyed porcupine quills and goose quills to decorate garments and basketry (fig. 1). Clothing was a very important aspect of First Nations culture; clothes and footwear were manufactured from tanned caribou hides and were adapted to the climate of the Subarctic. These clothes were decorated with sophisticated embroidery using dyed porcupine quills (but also moose hair or goose quills) and fringing ${ }^{1}$. Northern Athapaskan ${ }^{2}$ artefacts in particular are very rare, with significant collections including those of the Canadian Museum of Civilization and National Museums Scotland (NMS), the latter having the oldest and most extensive collection of 19th century Dene artefacts in the world today ${ }^{3}$.

In comparison to textile collections ${ }^{4}$, quillwork collections have received little systematic study and only limited information is available about the actual dye sources ${ }^{5}$ and dyeing processes used by native North Americans ${ }^{6}$. Earlier research suggested that only native dyes were used for quillwork dyeing without mordant, but our recent study of a group of dyed porcupine quills and objects collected in $1862^{7}$ from Northern Athapaskans (fig. 2) revealed that non-native dye sources (natural and semi-synthetic) were also used in combination with several metallic mordants (Fe, $\mathrm{Cu}$ and $\mathrm{Sn})^{8}$.

It is known that dyeing with the majority of natural dyes requires treatment of the textile substrates with an aqueous solution of mordant, generally a metal salt of aluminium, copper or iron. There is however no equivalent information available for quillwork dyeing. Sources of aluminium include biological accumulators of aluminium, potash alum $\left[\mathrm{AlK}\left(\mathrm{SO}_{4}\right)_{2} \bullet 12 \mathrm{H}_{2} \mathrm{O}\right]$, or ammonium alum $\left[\mathrm{Al}_{2}\left(\mathrm{NH}_{4}\right)_{2}\left(\mathrm{SO}_{4}\right)_{4} \bullet 12 \mathrm{H}_{2} \mathrm{O}\right]$. Sources of iron include green copperas $\left[\mathrm{Fe}\left(\mathrm{SO}_{4}\right) \bullet 7 \mathrm{H}_{2} \mathrm{O}\right]$, iron sulfate $\left[\mathrm{Fe}_{2}\left(\mathrm{SO}_{4}\right)_{3}\right]$ or iron oxide $\mathrm{Fe}_{2} \mathrm{O}_{3}$, while copper mordant was obtained from copper sulfate $\left[\mathrm{CuSO}_{4}\right]$ and tin mordant was prepared from the dissolution of pewter in concentrated nitric acid (aqua fortis) replaced later by tin salts $\left[\mathrm{SnCl}_{2}\right]^{9}$. During this treatment the mordant is absorbed by the fibre and a mordant-fibre complex or dye-mordant-fibre is created (scheme 1$)^{10}$. The choice of the mordant is important in the textile

Lore Troalen, Analytical Scientist, Collections Services Department, National Museums Scotland; Edinburgh, UK (l.troalen@nms.ac.uk). Thomas Calligaro, ingénieur de recherche, Centre de Recherche et de Restauration des Musées de France (thomas.calligaro@culture.gouv.fr). Claire Pacheco, ingénieur de recherche, Centre de Recherche et de Restauration des Musées de France (claire.pacheco@culture.gouv.fr). Alison N. Hulme, Senior Lecturer, EaStCHEM School of Chemistry; Edinburgh, UK (Alison.Hulme@ed.ac.uk). 


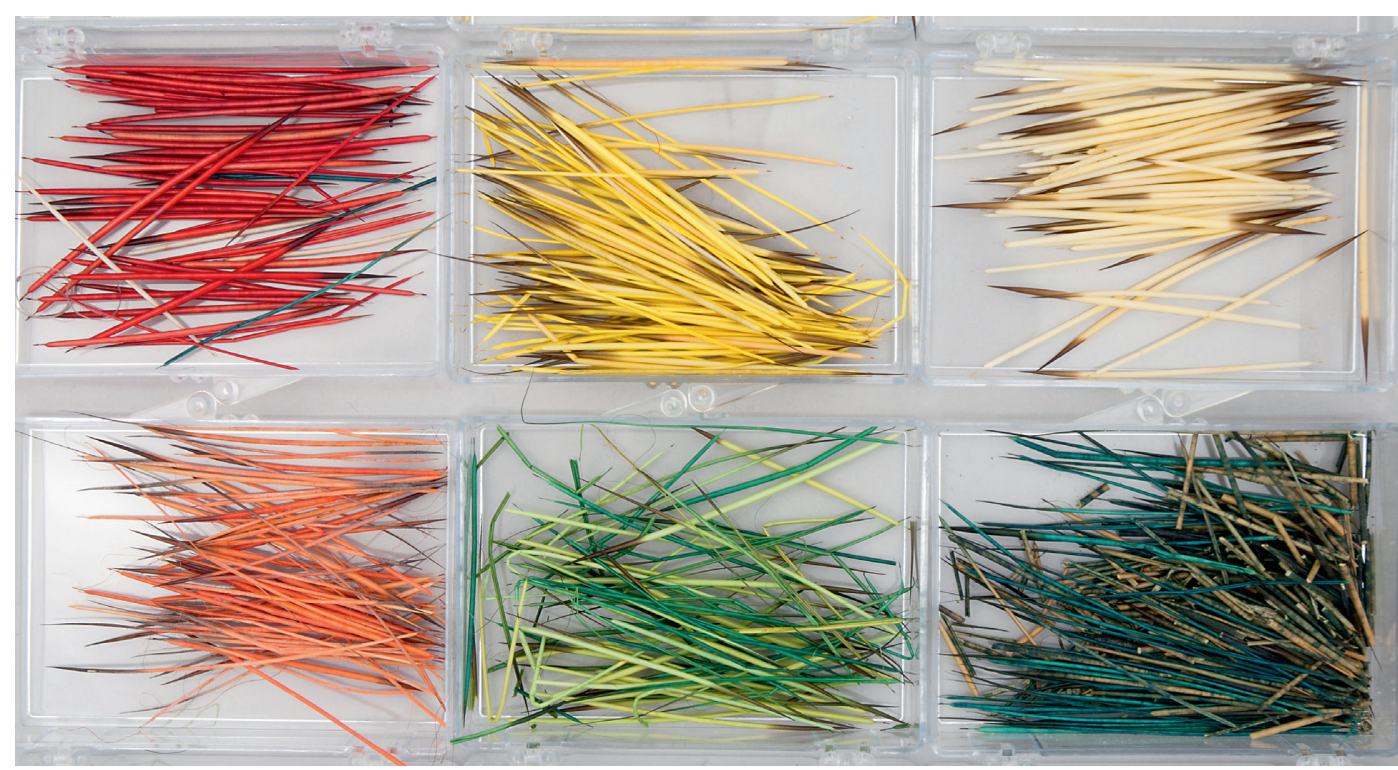

Fig. 2. Specimens of dyed porcupine quills collected in 1862 from Northern Athapaskans (Acc. $\mathrm{N}^{\circ}$ : A.848.15), (c) National Museums Scotland/Photography Isabell Wagner. preparation as it will affect greatly the final colour of the textile: for example the use of copper salts will darken the colour of the dye while in contrast the use of tin salts will brighten the colour.

Due to the difficulties in sampling quillwork for analysis, in this paper we explore the use of the highly sensitive techniques, non-invasive Particle Induced X-Ray Emission (PIXE) and Rutherford Backscattering Spectrometry (RBS) to characterise metallic residues in porcupine quillwork. Although PIXE and to a lesser extend RBS techniques are well established for the study of museum objects ${ }^{11}$, their application to organic-based materials is much more limited ${ }^{12}$. In order to better understand the sorption of metallic mordants on porcupine quill substrates, we additionally analysed replicate porcupine quill reference samples prepared in house with a range of concentration of copper(II) and tin(II) ions.

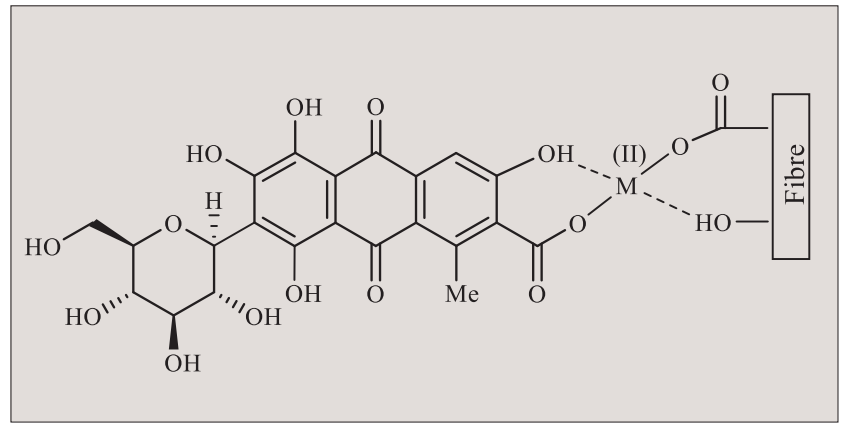

Scheme 1. Example of complex formed during the dyeing processes between an anthraquinone dye molecule, a metallic mordant (M) and the side-chain groups of a proteinaceous fibre.

\section{Materials and methods}

\section{Reference specimens}

Porcupine quills (Erethizon sp.) purchased from Native American artist Sarah Tronti were scoured and then dyed with either (i) cochineal (Dactylopius coccus C.) purchased from DBH Ltd Poole England, or (ii) turmeric (Curcuma longa L.) purchased from George Weil \& Sons Ltd. Mordants, including alum, copper(II) sulfate, tin(II) chloride, iron(II) sulfate, chromium(IV) oxide, and cream of tartar were purchased from George Weil \& Sons Ltd. Typically, dry quills $(0.3 \mathrm{~g})$ were dyed in a solution containing dyestuff (33 wt.\%) and metallic mordants (25 wt. $\%$ alum, or 5-6 wt. $\%$ otherwise) for $1 \mathrm{~h}$ at $85-90{ }^{\circ} \mathrm{C}$, as is traditionally reported for wool dyeing $^{13}$. Additionally, a set of porcupine quills were prepared by dyeing several quills $(0.2 \mathrm{~g})$ in a $50 \mathrm{~mL}$ dyebath containing cochineal dye $(2.00 \mathrm{~g})$ and variable amounts of copper(II) sulfate (> $99 \%$, Sigma Aldrich) and a second dyebath with variable amounts of tin(II) chloride (>99\%, Sigma Aldrich) in order to obtain dyebath concentrations in $\mathrm{Cu}$ (II) or $\mathrm{Sn}$ (II) of $100 ; 500 ; 1000$ and 2500 ppm.

\section{Particle Induced X-Ray Emission and Rutherford Backscattered Spectrometry (PIXE/RBS)}

Analyses were performed at the external beamline of the AGLAE facility with a $3 \mathrm{MeV}$ proton beam and a final analytical spot size of $50 \mu \mathrm{m}$, two $\mathrm{Si}(\mathrm{Li})$ detectors for PIXE analysis (with $125 \mu \mathrm{m}$ Be filter and $28.5 \mathrm{~mm}$ air for High Energy detector $)^{14}$. Additional PIXE measurements were performed using a newly implemented detection system with two Peltiercooled SDD detectors ${ }^{15}$. Simultaneous RBS analyses were performed using a charged particle detector in IBM 
geometry ${ }^{16}$, with a scattering angle of $150^{\circ}$. All measurements were undertaken in a He-rich atmosphere. In order to decrease, or avoid, a visible modification of the quill under the beam, a beam current of 3-6 pA was used and an area of $100 \times 500$ $\mu \mathrm{m}$ was scanned for an average of 4-5 minutes. Quantitative analysis was performed in trace mode using GUPIXWIN and TRAUPIXE software ${ }^{17}$, modelling a thick layer of keratin using the elements $\mathrm{C}, \mathrm{H}, \mathrm{N}, \mathrm{O}, \mathrm{S}$ in proportion to their reported relative wt. $\%^{18}$. RBS spectra were simulated with SIMNRA software $^{19}$ taking into account non-Rutherford reactions for the light elements in keratin $(\mathrm{C}, \mathrm{N}, \mathrm{O})^{20}$.

\section{Investigation of metallic residues in quillwork by PIXE-RBS techniques}

\section{PIXE analysis of modern replicate porcupine quills}

Porcupine quills are made of hard $\alpha$-keratin ${ }^{21}$ and present a highly crystalline structure, with the external layer of the quill (cuticle) being less ordered compared to the internal layer of the quill ${ }^{22}$. Although there are extensive studies on the properties of wool and hair fibres, or feathers, especially with regard to their uptake of dyes and metal ions ${ }^{23}$, there are only a very limited number of studies on porcupine quills and their dyeing properties ${ }^{24}$.

In contrast to wool fibres, where the dyestuff is evenly distributed through the fibre, generally only the thin cuticle layer of quills interacts with the dyebath and adsorbs the dyestuffs and metal ions ${ }^{25}$. The thickness of this cuticle averages $60 \mu \mathrm{m}$, while the range of the $3 \mathrm{MeV}$ protons PIXE beam has been evaluated as $136 \mu \mathrm{m}$ for a matrix of keratin by TRIM software (SRIM 2003 version) ${ }^{26}$. The effective depth values have been calculated for a range of elements using the GUCSA module of GUPIX software and vary between a minimum of $52 \mu \mathrm{m}$ for $\mathrm{S}\left(\mathrm{K}_{\alpha}\right)$ and a maximum of $80 \mu \mathrm{m}$ for $\mathrm{Hg}\left(\mathrm{L}_{\alpha}\right)$. These effective depth values mean that the concentration of mordant determined by PIXE corresponds to the average value of mordant present in the cuticle layer, and in cases where the cuticle is thinner to the contribution of mordant present in both the cuticle and the cortex. The limit of detection (LoD) of each element was averaged from 50 to 70 measurements using GUPIX software ${ }^{27}$ and calculated for both experimental set-ups. LoDs ranged between $3 \mathrm{ppm}$ for $\mathrm{Fe}\left(\mathrm{K}_{\alpha}\right)$ and $60 \mathrm{ppm}$ for $\operatorname{Sn}\left(L_{\alpha}\right)$.

It is known that the uptake of metal ions on keratinous substrates is variable between ions ${ }^{28}$ and depends on the treatment time and temperature, with longer heating times and higher temperatures giving rise to a substantial increase in the total uptake of metal ions by the substrates ${ }^{29}$. PIXE analysis of a small set of modern replicate quills prepared with dyebaths containing combinations of cream of tartar, alum, $\mathrm{Cr}, \mathrm{Fe}, \mathrm{Cu}$ and $\mathrm{Sn}$ showed that it was possible to differentiate the individual dyebath processes (table 1). It was found that the levels of $\mathrm{S}$ in modern replicate quills ranged between 2 and 4 wt.\%, as would be expected in keratin. Traces of $\mathrm{Zn}$ were detected in all the modern replicate quills, including a scoured one, at an average concentration of $50 \mathrm{ppm}$.

In order to better understand the sorption of copper and tin onto porcupine quills, we additionally analysed quills prepared with various concentrations of $\mathrm{Cu}$ (II) and $\mathrm{Sn}(\mathrm{II})$ mordants. PIXE analysis showed that these replicate quills present significant heterogeneity both across the surface of any one individual quill and between individual quills; as a result multiple measurements taken on different quills prepared using the same dyebath conditions gave $20-25 \%$ variation in the values obtained for metal ion concentrations. Nevertheless, it is clear from these experiments that the uptake of $\mathrm{Cu}(\mathrm{II})$ and $\mathrm{Sn}(\mathrm{II})$ in the cuticle layer increases with increasing dyebath concentrations and that $\mathrm{Sn}$ (II) ions exhibit a higher affinity than $\mathrm{Cu}(\mathrm{II})$ ions for the quill substrate (fig. 3).

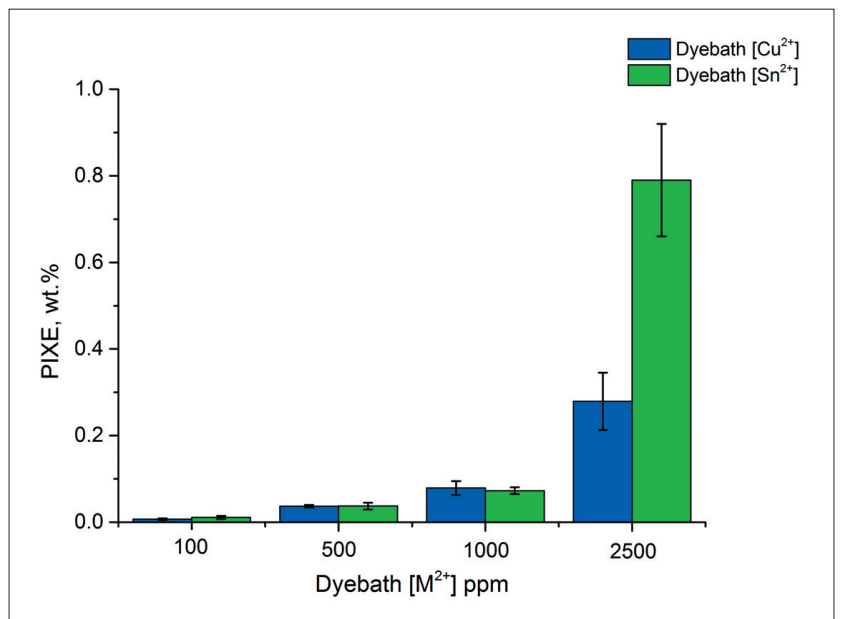

Fig. 3. Comparison of the sorption of $\mathrm{Cu}(\mathrm{II})$ and $\mathrm{Sn}(\mathrm{II})$ onto porcupine quills as measured by PIXE (wt.\%) with varying dyebath concentrations of the metal ion (ppm). For each dyebath concentration, 4 to 5 measurements on multiple quills were undertaken by PIXE; data are presented as the mean of these measurements with error bars depicting one standard deviation of the variation in measurements.

It is known that $\mathrm{Sn}$ (IV) has a strong affinity for wool substrates $^{30}$, and is therefore likely, despite the different oxidation state, that $\mathrm{Sn}$ (II) would also have a high affinity for porcupine quill substrates. Furthermore, in the case of $\mathrm{Sn}(\mathrm{II})$, there is a distinct possibility that under the dyebath conditions used, some reaction could have occurred between the catechol unit of carminic acid and Sn(II) ions leading to the formation of a Sn(IV)-catechol ligand, as has been observed in other studies $^{31}$. Finally, residual levels of $\mathrm{S}$ and $\mathrm{Cl}$ were observed in the replicate quills prepared with $\mathrm{CuSO}_{4}$ and $\mathrm{SnCl}_{2}$ respectively, with these levels increasing with increasing dyebath concentrations (table 1). 
Table 1. PIXE elemental data obtained with the High Energy detector for a

selection of modern quills. Entries marked "•" correspond to an average of 3 to 5

measurements from several quills prepared in the same dyebath conditions;

PIXE analysis entries marked " $a$ " correspond to a level below LoD.

\begin{tabular}{|c|c|c|c|c|c|c|c|c|c|c|c|}
\hline & PIXE & & & & & & & & & & \\
\hline Entry & $\begin{array}{c}S \\
(w t . \%)\end{array}$ & $\begin{array}{c}C l \\
(p p m)\end{array}$ & $\begin{array}{c}\boldsymbol{K} \\
(p p m)\end{array}$ & $\begin{array}{c}\boldsymbol{C a} \\
(p p m)\end{array}$ & $\begin{array}{c}\boldsymbol{C r} \\
(p p m)\end{array}$ & $\begin{array}{c}\boldsymbol{F e} \\
(p p m)\end{array}$ & $\begin{array}{c}\boldsymbol{Z n} \\
(p p m)\end{array}$ & $\begin{array}{c}A s \\
(p p m)\end{array}$ & $\begin{array}{c}\boldsymbol{H g} \\
(p p m)\end{array}$ & $\begin{array}{c}S \boldsymbol{S n} \\
(p p m)\end{array}$ & $\begin{array}{c}\boldsymbol{C u} \\
(p p m)\end{array}$ \\
\hline \multicolumn{12}{|l|}{ Modern replicate quills } \\
\hline Scoured quill & 2.8 & 836 & - & 350 & - & 10 & 68 & $a$ & $\alpha$ & $a$ & $a$ \\
\hline $\mathrm{Al}, \mathrm{K}, \mathrm{Cr}$ & 1.6 & 49 & 3944 & 379 & 1280 & 8 & 87 & $\alpha$ & $a$ & $a$ & 5 \\
\hline $\mathrm{Al}, \mathrm{K}, \mathrm{Sn}$ & 2.3 & 799 & 4173 & 702 & $a$ & 8 & 55 & $a$ & $a$ & 480 & 7 \\
\hline $\mathrm{Cu}$ & 3.1 & 76 & 380 & 111 & $a$ & $a$ & 32 & $a$ & $\alpha$ & $a$ & 224 \\
\hline $\mathrm{K}, \mathrm{Fe}$ & 4.0 & 4693 & 2460 & 109 & $a$ & 101 & 18 & $a$ & $a$ & $a$ & $a$ \\
\hline $\mathrm{Cu}, 100 \mathrm{ppm} \bullet$ & 2.2 & 89 & 1984 & 796 & - & 7 & 48 & - & - & - & 70 \\
\hline $\mathrm{Cu}, 500 \mathrm{ppm} \bullet$ & 2.3 & 207 & 1675 & 939 & - & 5 & 43 & - & - & - & 367 \\
\hline $\mathrm{Cu}, 1000 \mathrm{ppm} \bullet$ & 3.4 & 268 & 303 & 756 & - & 8 & 27 & - & - & - & 794 \\
\hline $\mathrm{Cu}, 2500 \mathrm{ppm} \bullet$ & 3.2 & 378 & 648 & 1201 & - & 6 & 44 & - & - & - & 2788 \\
\hline Sn, $100 \mathrm{ppm} \bullet$ & 2.3 & 192 & 3502 & 618 & - & 12 & 49 & - & - & 109 & - \\
\hline Sn, $500 \mathrm{ppm} \bullet$ & 2.0 & 1385 & 845 & 5536 & - & 4 & 45 & - & - & 373 & 6 \\
\hline Sn, $1000 \mathrm{ppm} \bullet$ & 2.3 & 4018 & 2077 & 751 & - & 3 & 35 & - & - & 726 & 8 \\
\hline Sn, 2500 ppm (dyebath 1) • & 1.3 & 11294 & 621 & 1108 & - & 3 & 23 & - & - & 7866 & 92 \\
\hline
\end{tabular}

\section{RBS analysis}

The quills were simultaneously analysed by RBS which provided additional information on the depth-profiling of the mordant in the cuticle layer. For the majority of the samples a two-layered model was used for simulation with SIMNRA software, comprising a thin layer of keratin containing traces of heavy metals over an infinite layer of keratin (fig. $4 \mathrm{a}$ ). The thickness of Layer 1 was evaluated to $\sim 80000 \times 10^{15}$ Atoms $\mathrm{cm}^{-2}$ which is equivalent to $9 \mu \mathrm{m}$ considering the atomic composition and density of keratin. This layer also presents a "roughness" of $\sim 40000 \times 10^{15}$ Atoms $\mathrm{cm}^{-2}$, which is equivalent to a gradient in composition (table 2 ). This model showed a good correlation for the RBS spectra obtained from scoured (fig. 4b) and mordanted modern quills (fig. 4c-d), Cu and Sn were observed in the RBS spectra of the reference quills for concentrations as low as 200-300 ppm (fig. 4c). However, it was not possible to differentiate the contribution of $\mathrm{S}$ and $\mathrm{Cl}$ elements in the SIMNRA simulation in the quills prepared with $\mathrm{SnCl}_{2}$ due to their close kinematic factors (fig. 4d).

For all the samples, the composition of Layers 1 and 2 was found to closely match the expected atomic concentrations for keratin, with the addition of traces of mordant (table 2$)^{32}$. However, in all the samples analysed it was observed that the level of S and mordant was found to be higher in Layer 1 (4 to $5 \mathrm{wt} . \%$ for $\mathrm{S}$ ) than the average values determined by PIXE

\begin{tabular}{|c|c|c|c|c|c|c|c|c|c|}
\hline & \multicolumn{2}{|c|}{$\times 10^{15}$ Atoms cm ${ }^{-2}$} & \multicolumn{3}{|c|}{ \% Atomic Composition } & \multirow[b]{2}{*}{$\mathbf{S}$} & \multirow[b]{2}{*}{$\mathbf{N}$} & \multirow[b]{2}{*}{ Sn } & \multirow[b]{2}{*}{$\mathbf{C u}$} \\
\hline & Thickness & Roughness & $\mathbf{C}$ & $\mathbf{H}$ & $\mathbf{O}$ & & & & \\
\hline \multicolumn{10}{|c|}{ Scoured quills } \\
\hline Layer 1 & 80000 & 40000 & 33.0 & 47.5 & 10.0 & 1.5 & 8.0 & - & - \\
\hline Layer 2 & Infinite & & 33.0 & 44.3 & 13.0 & 0.7 & 9.0 & - & - \\
\hline \multicolumn{10}{|c|}{ Modern quills: $\mathrm{Cu}(\mathrm{II}), 500 \mathrm{ppm}$} \\
\hline Layer 1 & 60000 & 50000 & 33.0 & 45.2 & 12.0 & 0.7 & 9.0 & - & 0.07 \\
\hline Layer 2 & Infinite & & 33.0 & 47.8 & 10.0 & 0.2 & 9.0 & - & - \\
\hline \multicolumn{10}{|c|}{ Modern quills: Sn(II), 2500 ppm (dyebath 1) } \\
\hline Layer 1 & 45000 & 40000 & 33.0 & 43.2 & 13.0 & 1.5 & 9.0 & 0.3 & - \\
\hline Layer 2 & Infinite & & 33.0 & 46.8 & 10.2 & 1.1 & 9.0 & - & - \\
\hline
\end{tabular}

Table 2.\% Atomic composition of the postulated layers in the SIMNRA simulation of: scoured modern replicate quills; modern replicate quills mordanted with $\mathrm{CuSO}_{4}$ (500 ppm); modern replicate quills mordanted with $\mathrm{SnCl}_{2}(2500 \mathrm{ppm})$. 


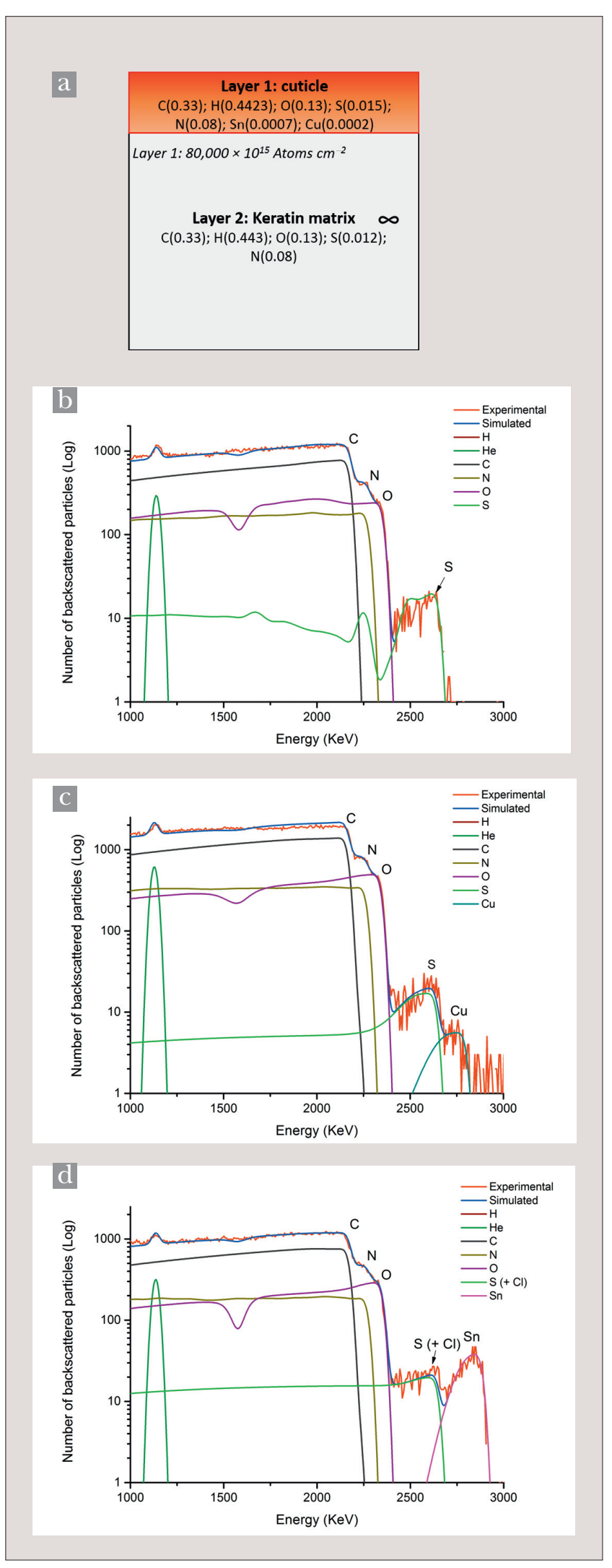

Fig 4. (a) Two-layered model used for SIMNRA simulation; with atomic compositions and layer thicknesses in Atoms $\mathrm{cm}^{-2}$ provided by the SIMNRA simulation; experimental and simulated RBS spectra obtained with a $3 \mathrm{MeV}$ proton-beam on (b) a scoured modern quill, (c) a quill prepared with a $500 \mathrm{ppm} \mathrm{CuSO}_{4}$ dyebath solution and (d) a quill prepared with $2500 \mathrm{ppm} \mathrm{SnCl}_{2}$ dyebath solution.
(1.5 to $2.5 \mathrm{wt}$ \% for $\mathrm{S}$ ). While a higher level of $\mathrm{S}$ is expected in the outer cuticle ${ }^{33}$, the higher levels of mordants could possibly correspond to a deposition on the surface of the cuticle.

\section{Conclusion}

The combination of PIXE and RBS analysis provides an alternative non-destructive methodology for the study of these keratin-based materials. While PIXE analysis allows the concentrations of various mordants $(\mathrm{Fe}, \mathrm{Cu}, \mathrm{Sn})$ at the surface of the quills to be determined, RBS allows additional depthprofiling of the mordants at the surface of the quills to be obtained. The concentrations and distribution of metal ions have been determined on modern replicate porcupine quills prepared using known dyebath concentrations of these ions.

These results present a promising approach for the study of quillwork and related keratinous materials. Future investigation might focus on the analysis of modern replicate quills prepared with successive dyebaths containing either different mordant or dyestuff combinations to investigate the effects of overdyeing processes on the metal ion concentrations observed. From a methodological point of view, the results presented were obtained during the development of the new AGLAE multi-detector, before the automated imaging system was installed. Thus future study of these fragile materials should include PIXE and RBS mapping (which should soon be possible at the AGLAE), as well as analysis by total IBA technique.

\section{Acknowledgments}

We thank C. Knowles, H. Lidchi, N. McLean and I. Wagner at NMS; the AGLAE team especially L. Pichon for their precious help. L. Beck is gratefully acknowledged for early RBS testing on modern quill specimens. Financial assistance was provided through the Science and Heritage programme (studentship to LGT, Grant ref. CDA08/411) and National Museums Scotland. Additional financial support was provided by the Access to Research Infrastructures activity in the 7th Framework Programme of the EU (CHARISMA Grant Agreement n. 228330) for AGLAE access. 


\section{Notes}

1. Thompson (1994), p. XIII-XVI and p. 3-20.

2. The term Athapaskan refers to both a cultural group and a language family, see Krauss and Golla (1981), p. 67-85. Athapaskans, also called "Dene" can be subdivided into three groups, Northern, Pacific Coast and Southern. Northern Athapaskans include the Tłıcho, the Gwich'in, the Slavey, and the Chypewyan, all living from the Hudson's Bay in the east to the interior of the Alaska coast in the west, Thompson (1990), p. 3-9.

3. For National Museums Scotland Athapaskan collection, see publications from Mc Fayden Clark and Idiens (1974), p. 13-43; Idiens (1979), p. 1-20; Knowles (2007), p. 37-56. Additional examples of Northern Athapaskan quillwork from the McKenzie River district (Bata Shoe Museum) may be found in Thompson (1990), op. cit. (note 2), p. 11-21.

4. A review of the dye sources used in European historical textile dyeing can be found in Ferreira et al. (2004), p. 329-336.

5. See Cole and Heald (2010), p. 1-6; Cole (2010), p. 102-160 for the investigation of dye sources in pre-1856 Eastern Woodlands quillwork; See Troalen (2013) p. 204-254; Troalen et al. (2016), p. 83-91 for dye sources in 1862 Athapaksan quillwork.

6. Orchard (1919), p. 6-8 and the recent review on the documentary sources describing quill dyeing techniques, Bohr and Lindsay (2009), p. 21-35; See additionally Troalen (2013) op. cit. (note 5) and Troalen et al. (2016) op. cit. (note 5).

7. The Athapaskan quill specimens from National Museums Scotland were previously described as "natural, and some coloured in red and blue with European aniline dyes", probably due to their bright colours. MacFayden Clark and Idiens (1974), op. cit. (note 3), p. 102.

8. Troalen (2013), op. cit. (note 5);

Troalen et al. (2016), op. cit. (note 5).

9. Cardon and du Châtenet (1990), p. 21-24; Hofenk de Graaf (2005), p. 22-23

and Ferreira et al. (2004), op. cit. (note 4).

10. Ferreira et al. (2004), op. cit. (note 4).

11. Calligaro, Dran and Salomon

(2004), p. 227-276; Beck et al. (2010), p. 2086-2091; Albéric et al. (2015), p. 100-108 p. $100-108$

12. Beck et al. (2012), p. 203-207.

13. Cardon and du Châtenet (1990), op. cit. (note 9$)$.

14. Pichon et al. (2010), p. 2028-203.

15. Pichon et al. (2014), p. 27-31.

16. Pichon et al. (2010), op. cit.

(note 14).

17. Campbell et al. (2010), p. 3356-3363; Pichon et al. (2010), op. cit. (note 14); Pichon et al. (2015), p. 45-54.

18. Masson (1963), p. 179-180; Zahn et al. (2000), p. 548-576. 344.

19. Eckstein and Mayer (1999), p. 337-

20. Beck et al. (2012), op. cit. (note 12).

21. MacArthur (1943), p. 38-41; Fraser,

McRae, Rogers (1972), p. 83-110.

22. Busson, Engström, Doucet (1999), p. 1021-1030.
23. Fergusson, Holzbecher, Ryan (1983), p. 121-135; Carr, Evans, Roberts (1987), p. 109-113; Suyama, Fukazawa, Suzumara (1996), p. 67-74; Kar and Misra (2004), p. 1313-1319.

24. Bohr and Lindsay (2009), op. cit. (note 6); Troalen (2013), op. cit. (note 5).

25. Troalen et al. (2016), op. cit. (note 5). 26. Biersack and Haggmark (1980), p. $257-269$.

27. Campbell et al. (2010), op. cit. (note 18).

28. Fergusson, Holzbecher, Ryan (1983), op. cit. (note 23).

29. Suyama, Fukazawa, Suzumara (1996), op. cit. (note 23); Sheffield and Doyle (2005), p. 203-207.

30. Sakaguchi (1969), p. 1053-1055.

31. Wakley and Varga (1972), p. 169-

178; Budesinsky (1972), p. 909-910;

Hernández Méndez et al. (1987), p. 288-292.

32. Troalen et al. (2016), op. cit. (note 5).

33. Bradbury et al. (1966), p. 1333-1334.

\section{References}

Albéric M., Müller K., Pichon L., Lemasson Q., Moignard B., Pacheco C., Fontan E., Reiche I., 2015, "Non-invasive quantitative micro-PIXE-RBS/EBS/

EBS imaging reveals the lost polychromy and gilding of the NeoAssyrian ivories from the Louvre collection", Talanta, 137, p. 100-108.

Beck L., De Viguerie L., Walter Ph., Pichon L., Gutiérrez P.C., Salomon J., Menu M., Sorieul S., 2010, "New approaches for investigating paintings by ion beam techniques", Nuclear Instruments and Methods B, 268, p. 2086-2091.

Beck L., Cuif J.-P., Pichon L., Vaubaillon S., Dambricourt Malassé A., Abel R.L., 2012, "Checking collagen preservation in archaeological bone by nondestructive studies (Micro-CT and IBA)", Nuclear Instruments and Methods $B, 273$, p. 203-207.

Biersack J. P., Haggmark L.G., 1980, "A Monte Carlo computer program for the transport of energetic ions in amorphous targets", Nuclear Instruments and Methods 174, p. 257-269.

Bohr R., Lindsay A., 2009, "Dyeing commodities whether in Roote or floure: Reconstructing Aboriginal Dye Techniques from Documentary and Museum Sources", Material Culture Review, 69, p. 21-35.

Bradbury J. H., Chapman G. V., Hambly A. N., King N. L. R., 1966, "Separation of chemically unmodified histological components of keratin fibres and analyses of cuticle", Nature, 2010, p. 1333-1334.

Budesinsky B.W., 1972, "The complexation of tin(IV) with catechol violet", Analyst, 97, p. 909-910.

Busson B., Engström P., Doucet J., 1999, "Existence of various structural zones in keratinous tissues revealed by X-ray microdiffraction", Journal of Synchrotron Radiation, 6, p. 1021-1030.
Calligaro T., Dran J.-C., Salomon J., 2004

"Ion beam microanalysis", in: Nondestructive microanalysis of cultural heritage materials, Janssens K., van Grieken R. (eds.), Wilson and Wilson's, comprehensive analytical chemistry, 42, Amsterdam: Elsevier, p. 227-276.

Campbell J. L., Boyd N. I., Grassi N., Bonnick P., Maxwell J.A., 2010, "The Guelph PIXE software package IV”, Nuclear Instruments and Methods B, 268, p. 3356-3363.

Cardon D., Du Châtenet G., 1990, Guide des teintures naturelles. Plantes - Lichens Champignons - Mollusques et Insectes, Delachaux et Niestlé, Paris.

Carr C.M., Evans J.C., Roberts W., 1987, “An $\mathrm{X}$-ray photoelectron and electron spin resonance study of wool treated with aqueous solutions of chromium and copper ions", Textile Research Journal, 57, p. 109-113.

Cole C., Heald S., 2010, "The history and analysis of pre-aniline Native American quillwork dyes", Textile Society of America Symposium Proceedings. Paper 14, p. 1-6. http://digitalcommons.unl.edu/tsaconf/14

Eckstein W., Mayer M., 1999, "Rutherford backscattering from layered structures beyond the single scattering model", Nuclear Instruments and Methods B, 153, p. 337-344.

Fergusson J. E., Holzbecher J., Ryan D. E., 1983, "The sorption of copper(II), manganese(II), zinc(II) and arsenic(II) onto human hair and their desorption", Science of Total Environment, 26, p. 121-135.

Ferreira E. S. B., McNab H., Hulme A. N., Quye A., 2004, "The natural constituents of historical textile dyes", Chemical Society Reviews, 33, p. 329-336.

Fraser R. D. B., McRae T. P., Rogers G.E., 1972, Keratins, their composition, structure and biosynthesis, Springfield Ill., Thomas Publishers.

Hernández Méndez J., Moreno Cordero B., Carabias Mártinez R., Gutiérrez Dávila L., 1987, "Spectrophotometric determination of tin (IV) with catechol violet sensitized with polyvinylpirrolidone", Microchemical Journal, 35, p. 288-292.

Hofenk De Graaf J. H., 2005, The colourful Past, Archetype Publications.

Idiens D., 1979, A catalogue of Northern Athapaskan Indian Artefacts in the collection of the Royal Scottish Museum, Edinburgh, Royal Scottish Museum Information Series, Art and Archaeology (3).

Kar P., Misra M., 2004, "Use of keratin fibre for separation of heavy metals from water", Journal of Chemical Technology and Biotechnology, 79, p. 1313-1319.

Knowles C., 2008, "Objects journeys: outreach work between National Museums Scotland and the Tłıcho", in: Material Histories, Marischal Museum, University of Aberdeen, p. 37-56.

Krauss M. E., Golla V.K., 1981, "Northern Athapaskan Languages", in Handbook of North American Indians, Vol. 6, Subarctic, Sturtevant, W. C. (ed.), Smithsonian Institution, Washington DC, p. 67-85. 
MacArthur I., 1943, "Structure of a-keratin", Nature, 152, p. 38-41.

Mc Fayden Clarke A. and Idiens D., 1974, The Athapaskans: Strangers of the North. Ottawa: National Museum of Man.

Masson P., 1963, "Density and Structure of Alpha-Keratin”, Nature, 197, p. 179-180.

Orchard, William C., 1916, (reprinted 2009), The technique of porcupine-quill decoration among the North American Indians, Kessinger Publishing.

Pichon L., Beck L., Walter Ph., Moignard B., Guillou T., 2010, "A new mapping acquisition and processing system for simultaneous PIXE-RBS analysis with external beam", Nuclear Instruments and Methods B, 268, p. 2028-2033.

Pichon L., Moignard B., Lemasson Q., Pacheco C., Walter Ph., 2014, "Development of a multi-detector and a systematic system on the AGLAE external beam", Nuclear Instruments and Methods B, 318, p. 27-31.

Pichon L., Calligaro T., Lemasson Q., Moignard B., Pacheco C., 2015, "Programs for visualization, handling and quantification of PIXE maps at the
AGLAE facility", Nuclear Instruments and Methods B, 363, p. 48-54.

Sakaguchi I., 1969, "Cumulative tinweighting of silk with stannic chloride", Textile Research Journal, 39, p. 1053-1055.

Sheffield A., Doyle M. J., 2005, "Uptake of copper(II) by wool", Textile Research Journal, 75, p. 203-207.

Suyama K., Fukazawa Y., Suzumara H., 1996, "Biosorption of precious metal ions by chicken feather", Applied Biochemistry and Biotechnology, 57/58, p. 67-74.

Thompson J., 1990, Pride of the Indian wardrobe: Northern Athapaskan footwear, Bata Shoe Museum Foundation, University of Toronto press.

Thompson J., 1994, From the Land: Two hundred years of Dene clothing, Canadian Museum of Civilization.

Troalen L. G., Röhrs S., Calligaro T., Pacheco C., Kunz S., Del HoyoMeléndez J. M., Hulme A. N., 2016, "A multi-analytical approach towards the investigation of Subarctic Athapaskan colouring of quillwork and its sensitivity to photo-degradation", Microchemical Journal, 126, p. 83-91.
Wakley W. D., Varga, L.P., 1972, “Stability constants of tin-pyrocatechol violet complexes from computer analysis of absorption spectra”, Analytical Chemistry, 44, p. $169-178$.

Zahn H., Wortmann F. J., Wortmann G., Schäfer K., Hoffmann R., Finch R., 2000, "Wool", in: Ullmann's Encyclopaedia of Industrial Chemistry, Vol 39, Wiley-VCH Verlag GmbH \& Co, p. 548-576.

\section{Unpublished work:}

Cole, C. L., 2010, The contextual analysis of pre-1856 Eastern Woodlands quillwork dyes through identification by Liquid Chromatography - Mass Spectrometry, University of Delaware, Ph.D. Thesis.

Troalen L. G., 2013, Historic dye analysis: method development and new applications in cultural heritage, The University of Edinburgh, Ph.D. Thesis. 